\title{
Co-Branding Internationally: Everyone Wins?
}

Linda C. Ueltschy, (E-mail: ueltsch@cba.bgsu.edu), Bowling Green State University Michel Laroche (E-mail: laroche@ mercato.concordia.ca), Concordia University, Canada

\begin{abstract}
Co-branding is an increasingly popular technique used primarily in domestic markets to transfer the positive associations of the partner brands to a newly formed co-brand. This exploratory study investigates the relative impact of the brand equity of the constituent brands on co-branding efforts internationally using a sample of 1,203 Philippine housewives. Findings indicate the co-branding of two high-equity brands was mutually beneficial, but the co-branding of high-equity and low-equity brands can be potentially dangerous for the high equity partner.
\end{abstract}

\section{Introduction}

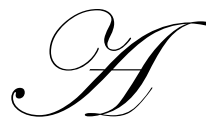

s globalization has accelerated, so has the choice of brands, both foreign and domestic (Hsieh< 2002). A brand has been defined as: "an identifiable product, service, person or place augmented in such a way that the buyer or user perceives relevant unique values which match their needs most closely" (de Chernatony, 1998,3). The associated incremental value added to the product by virtue of its brand has been referred to as its brand equity (Aaker, 1991; Keller, 1993). In today's competitive battleground, the concept of brand equity has proved to be an important source of strategic insight for marketers (Moore, Wilkie and Lutz, 2002, 17).

Brands play a critical role in establishing a firm's visibility and position in international markets (Douglas, 2001). With the globalization of markets and the growth of competition on a global scale, companies are increasingly acquiring firms in other countries and entering into alliances across national boundaries. One type of alliance being employed more frequently is a brand alliance between two different marketing organizations known as co-branding. Cobranding is a strategy that strives to capture the synergism of combining two well-known brands into a third, unique branded product (Rao and Ruekert, 1994). This increasingly popular technique has been used primarily in domestic markets with the goal of transferring the positive associations of the partner (constituent brand) brands to a newly formed co-brand (composite brand). This approach appears to be a win/win strategy in domestic markets for both co-branding partners (Washburn, Till and Priluck, 2000). However, empirical studies examining its impact in international markets have been surprisingly few.

The goal of this exploratory study is to investigate the relative impact of the brand equity of the constituent (original) brands on co-branding efforts internationally, as well as to examine the benefits and risks to the partner brands.

\section{Brands and Brand Equity}

Aaker (1991) defined a brand as an addition to a product which enables its identification. A brand is said to be a polyvisual expression of a set of values; these values are built on impressions about the product or service concerned, which help to differentiate the product or service in a desirable way and motivate the purchase decision (Blackett and Boad, 1999, 4). Brands signal product positions, improve consumer perceptions about brand attribute levels and increase confidence in brand claims (Erdem and Swait, 2001). They serve not only as associative cues, but also as predictive cues about product performance (Janiszewski and Osselaer, 2000). Consumers tend to perceive products from an overall perspective, associating with the brand all the attributes and satisfactions experienced by the purchase and use of the product (Vasquez, Del Rio and Iglesias, 2002). 
Interestingly, Wells $(2002,38)$ characterized brands as having the ability to "let the manufacturer reach over the shoulder of the retailer straight to the consumer." A brand is said to be "the living relationship between a person and a product or organization. It exists in the mind, the place where the tangibles and intangibles meet (Wiedmann, 1999, 2)." For branded consumer businesses, which need to communicate with large numbers of end users, the rewards of strong market position combined with clear customer preference can be large. If a firm is able to create a strong brand, it can attract customers and build barriers against competition (Brouthers and $\mathrm{Xu}, 2002$ ). Branding enables firms to differentiate their products, not only from the competition, but also from commodity products (Malhotra, Peterson and Kleiser, 1999). Thus, brands represent the most valuable asset that many firms possess and the associated brand equity is usually the result of years of developmental efforts (Green and Smith, 2002).

Srivastava and Shocker (1991) refer to brand equity as the added value that accrues to a product as a result of marketing investment and effort. Price premiums and market share have been closely associated with this increasingly salient concept (Chaudhuri and Holbrook, 2001). In Keller's (1998) customer-based brand equity framework, a brand's meaning is identified as the key to creating equity. Most behavioral models of brand equity emphasize the importance of brand knowledge and brand associations (Keller, 1998; Aaker, 1991). Vasquez, Del Rio and Iglesias $(2002,28)$ define consumer-based brand equity as "the overall utility that the consumer associates to the use and consumption of the brand, including the associations expressing both functional and symbolic utilities." Dillion et al. (2001) view brand equity as having two components: brand specific associations (features, attributes or benefits that customers link to the brand) and general or more holistic impressions about the brand. Erdem and Swait (2001) suggest that brand equity be viewed using signaling theory from informational economics (Stigler, 1961). The informational economic perspective considers the imperfect and asymmetrical informational structure of the market. It stresses credibility, determined endogenously by the dynamic interactions between firms and consumers, as the main determinant of consumer-based brand equity. Due to an upsurge in private labels and store brands, brand equity must clearly be sustained by high quality to maintain its competitive edge in the marketplace (Bello and Holbrook, 1995).

Firms enjoy a number of brand equity benefits related to growth and profits that ensue from increased customer loyalty levels. Thus, it is not surprising that branding is now acknowledged as a business discipline of the highest importance in the creation of competitive advantage and shareholder value. Therefore, the motive for brand ownership is clear: strong brands, because of their ability to command highly reliable income streams, offer economic benefits that add materially to the value of the organization. Branding has a strategic value which enables the firm to be successful even in the face of competition and recession (Temporal, 2000). Nowadays, brands are regarded as assets in their own rights and are subject to investment and evaluation in the same way that other business assets are. Indeed, they need to be nurtured and sustained through careful management and development so as to maximize profitability and minimize risk. Such a large number of brands across nations evokes issues of whether consumers perceive brands differently in different markets and consequently how the perceived brand image impacts consumer purchasing behavior. Because brand image is an integral part of brand equity, it could be expected that a brand's brand equity would vary according to the market.

\section{Co-Branding}

Co-branding reflects the true spirit of branding, which has to do with innovation and distinctiveness. It is a way to increase the scope and influence of brands, enter new markets, reduce costs through economies of scale and refresh a brand's image. For established brands, it offers the opportunity to create an entirely new income stream or to boost sales of existing products. For new brands, it may bring instant credibility in a normally sceptical marketplace. It is a widely used business strategy in industries like food and drinks, retailing, air travel and financial services, with the number of firms using it growing by forty percent/year (Blackett and Boad, 1999).

Park, Jun and Shocker (1996) define co-branding as the pairing of two or more branded products (constituent brands) to form a separate and unique product (composite brand). Similarly, Blackett and Boad (1999, xvi) view cobranding as the mutual enhancement of two brands through close association of a product or service. In the global arena, marketing managers are constantly presented with new opportunities as well as new threats, including in the area of branding strategies (Batra et al., 2000). If co-branding is properly handled, it can be a win-win situation. However, if it is not well thought out and correctly executed, one or both partners will suffer. A company needs to take care that in 
trying to attract new consumers to try the new version, or co-brand, it does not disenfranchise current brand users (Kirmani, Sood and Bridges, 1999). One critical market entry decision when a firm introduces a product into a foreign market is the choice of a brand name (Zhang and Schmitt, 2001). This choice of a brand name becomes even more important, and more complex, in the case of a new co-brand, because it will be an indicator of the perceived fit of the new co-brand, as well as a heuristic cue when consumers make product judgments.

A rationale frequently set forth for the proliferation of brand extensions and brand alliances is the motivation of companies to leverage the equity in established brands, thereby developing new profitable products relatively easily and with less cost. Balachander and Ghose (2003) found that advertising the new brand extension can have a positive spillover effect on the umbrella brand, resulting in less advertising expenditure for each product. Erdem and Sun (2002) also found evidence for the uncertainty reducing role of advertising for umbrella brands. The explanation for this phenomenon can be found in the works of Anderson (1983) where he offers a consumer memory-based explanation for the existence of reciprocal spillover effects using the associative network theory. Brand associations in consumer memory are thought to be a key component of brand equity and brand-related effects (Aaker, 1996). The associative network theory views knowledge about a brand as being a network of nodes (concepts) connected by links, which represent the associations between the concepts. The links vary in strength and this is an indication of the association strength between concepts. A consumer retrieves a particular piece of information from memory when the corresponding node is activated above a certain threshold level due to external cues such as advertising. Balachander and Ghose (2003) found that exposure to advertising of the brand extension (here the co-brand) activates the link to the parent brand because of the strength of the link between the two nodes, creating a positive spillover effect.

Research has shown that customer evaluations of co-brands are affected by the degree to which the skills and resources of the parent brands are perceived to fit with or generalize to the new co-brand (Klink and Smith, 2001). The theoretical foundations in the cognitive psychology literature suggests that similarity between a brand and an extension or alliance facilitates the transfer of knowledge, attitude and purchase intention (Martin and Stewart, 2001). In the case of co-branding, this says that how much affect and brand preference are transferred to the new co-brand from the original or constituent brands depends, at least in part, on the similarity of the products and the perceived fit of the brand alliance in the minds of consumers. Some researchers have suggested that similarity based on a common product usage occasion might be more theoretically meaningful than feature-based similarity (Ratneshwar and Shocker, 1991; Chakravarti, Macinnis and Nakamoto, 1989). The similarity of product features, or lack thereof, may have little to do with how consumers perceive the occasion on which a product might be used or the way in which product usage takes place. Thus, knowledge and attitudes might easily transfer from one product to another even though they have different physical forms; this is especially true for products that are complementary such as razors and shaving cream. In a co-branding setting, an example of this would be a co-brand of Ruffles potato chips with Maullers barbecue sauce (Washburn and Plank, 2002). Another example of this type of co-branding, known specifically as ingredient co-branding (Blackett and Boad, 1999) would be Coca Cola identifying the use of Nutra Sweet in Diet Coke or Compaq labeling its computers as having Intel inside. In any case, the less the incongruency between the brand identities and reputations of the constituent brands forming the new co-brand, the greater the resulting brand equity (Jevons and Gabbott, 2000).

Heilman, Bowman and Wright (2000) found that consumers new to a market or product category initially focus on low risk, big brand names. Similarly, Alba and Chattopadhyay (1985) found that greater product familiarity can reduce the inhibiting effect that dominant brands have on the retrieval of smaller brands names. In other words, greater product-related experience increases the likelihood that a consumer might try the "underdog." This is particularly germane to international branding strategies since consumers in developing countries are often unfamiliar even with a product category. Hence, they would first purchase brands with high brand equity. What then can a lesser known brand do to enter such markets? Co-branding with a high equity brand would be an excellent choice, assuming one could be found. Hillyer and Tikoo (1995) found that strong brand associations (i.e. high brand equity) of one brand can lend credibility to the other brand by serving as an augmenting cue in consumer evaluations. Consumers tend to infer that high equity brands will only associate with other high equity brands. However, conversely, a low equity brand might function as a discounting cue which could make consumers more hesitant to accept the claims of the high equity brand. Simonin and Ruth (1998) examined consumer attitudes toward brand alliances (co-brands) and found that consumers' attitudes toward the brand alliance (co-brand) influenced their subsequent attitudes toward the individual brands that comprised 
that alliance (the partner or constituent brands). Likewise, consumer attitudes toward partner brands prior to the alliance significantly influenced their attitudes toward the alliance or new co-brand. As Dawar and Pillutla (2000) point out, brand equity is a valuable yet fragile asset. A risk of co-branding is pairing with a partner that can damage the existing product's strong brand equity, since over time the two brands become linked together in a consumer's mind (Aaker, 1991). Thus, the following hypotheses are set forth:

H1: The product evaluation of the composite brand (the new co-brand), when a high equity brand is paired with a low equity brand, will be significantly higher than the product evaluation of the low equity brand.

H2: The product evaluation of the composite brand (the new co-brand), when a high equity brand is paired with a low equity brand, will be significantly lower than the product evaluation of the high equity brand.

H3: The product evaluation of the composite brand (the new co-brand), when a high equity brand is paired with another high equity brand, will be significantly higher than the product evaluation of either of the high equity brands.

\section{Objectives of This Study}

The objectives of this study are to investigate the effect of co-branding strategies on the brand equity of the partner brands as well as on the composite brand in one important international market, the Philippines. In this paper, we will try to answer the following questions: Do both constituent brands benefit as well as the new composite brand or are there truly dangers involved for the constituent brands? What is the contribution of the brand equity of the constituent brands to the perceived brand equity of the new co-brand?

\section{Market of Interest: The Philippines}

The Philippines is a major export market for U.S. firms, with a natural competitive advantage in its abundant supply of skilled and semi-skilled, English speaking workers. With a population of 78.3 million and a GDP which grew 4 percent in 2000, the Philippines is proving to be one of the stronger markets for ready to consume food and beverages from the United States because of close cultural and language ties. The value of U.S. exports in this product category continued an increasing trend in 2000 to $\$ 267$ million, with the Philippines being among the top twenty export markets for U.S. consumer ready products. As a member of the Association of Southeast Asian Nations (ASEAN), the Philippines is committed to reducing tariff and nontariff barriers, as well as investment restrictions. In fact, by the end of 2002, all tariff lines in the Inclusion list were between 0-5 percent (Country Commercial Guide 2002). Economic reforms have been aimed at deregulation and liberalization and toward ensuring a place for the Philippines in the global economy (Pernia, 1996). Data from the Philippines central bank showed that the country received U.S. \$185.7 million in foreign portfolio investment between January and July, 2002, which represents a more than eightfold increase from the same period the year before (Asia Weekly Financial Alert, 2002). Although its currency, the Philippine peso, has had its ups and downs in the last several years, inflation has remained low, at 4.4 percent in 2000, and U.S. exports to the Philippines grew by 21.6 percent in the same year and continue to climb.

Because it is a very brand-conscious society (Country Commercial Guide, 2002), the Philippines is a very attractive market for global corporations. Price and brand are said to be the primary considerations in the purchase decision of most Philippine buyers, so manufacturers/marketers are continually developing new brands to appeal to the different segments. Advertising plays a significant role in the Philippines in promoting the sale of most goods. In fact, it is growing as an industry at a rate faster than the GNP, with advertising expenditures exceeding $\$ 900$ million in 2000 (Country Commercial Guide, 2002).

Up until 1992, the United States operated several large military bases in the Philippines. The smuggling of goods from the PX (Post Exchange) located on these bases to large markets located adjacent to the bases was commonplace and conducted on a large scale (Hulland, Todino and Lecraw, 1996). Consequently, Filipinos developed both a knowledge of and affinity for U.S. consumer products. Hence, the emphasis placed on brand names, as well as the English speaking ability of most Filipinos, make the Philippines an ideal market for this study. 


\section{Methodology}

A field experiment and survey was conducted in four major metropolitan areas of the Philippines with interviewers hired from an international market research firm based in the Philippines doing home interviews with 1,203 Philippine adult respondents. Stratified random sampling was used to ensure that an adequate number of respondents from the upper, middle and lower classes were surveyed for this study. All levels of income, education and ages were well represented in the sample. All respondents were adult females, because it was suggested by the Philippine market research firm that they are the decision makers for purchases of the products chosen. The average age of the respondent was 31.2 years old and the average family size of the respondent was 5.1 people per household.

The Philippines was chosen as the site for this study because it is an Asian country where U. S. products are well known, while Canadian products have lower brand equity and less brand recognition in this market. These facts were confirmed by the Philippine market research firm and the pretest results. The sample is indeed a strength of this study; the use of 1,203 actual Philippine consumers certainly enhances the value of the research findings.

\section{Pretesting of Products and Brands}

Through a series of pretests with 335 Philippine respondents from the same metropolitan areas as the respondents in the sample, six product combinations were examined. Ramen noodles combined with a flavoring mix was selected as the most appropriate combination for this study. The respondents viewed the combination of these products as compatible and ramen noodles was a product category with which the subjects were very familiar.

Next, a number of brand names were pretested to select high and low equity brands for the possible pairing in this study. The high equity brand of noodles chosen was Maruchan (U.S.) and the low equity brand was Equality (Canada). These were both paired with the high equity brand Campbell's (U.S.) for the flavoring mix.

\section{Procedure}

Each respondent was first asked general demographic questions and then was shown a picture of a prototype package depicting either ramen noodles, ramen noodles with Campbell soup favoring mix or Campbell's soup flavoring mix. Each respondent saw only one picture, but the interviewers varied the pictures shown to respondents so that approximately equal numbers saw and responded to attribute questions about each of the five treatments in the experimental design using the brand equity questions. The treatments were as follows:

\begin{tabular}{l|l}
$\mathrm{T}_{1}-$ Maruchan Noodles (U.S.) $\mathrm{N}=294$ & $\mathrm{~T}_{2}-$ Equality Noodles (Canada) $\mathrm{N}=286$ \\
\hline $\mathrm{T}_{3}-\quad \begin{array}{l}\text { Maruchan Noodles (U.S.) with Campbell Soup flavoring } \\
\text { (U.S.) } \mathrm{N}=212\end{array}$ & \begin{tabular}{l}
$\mathrm{T}_{4}-\quad \begin{array}{l}\text { Equality Noodles (Canadian) with Campbell Soup } \\
\text { flavoring (U.S.) } \mathrm{N}=212\end{array}$ \\
\hline $\mathrm{T}_{5}-$ Campbell's Soup flavoring mix (U.S.) N=199
\end{tabular}
\end{tabular}

\section{Measures}

Yoo and Donthu's (1997) ten-item Multidimensional Brand Equity scale was employed to measure that construct in this study (see Appendix 1). This three-factor scale represents the original brand equity dimensions proposed by Aaker and was found by Washburn and Plank (2002) to be the best of the available brand equity scales, demonstrating composite reliability as well as suitability across culturally diverse samples. The brand equity items were evaluated on a seven point Likert-like scale, where $1=$ strongly disagree and $7=$ strongly agree. The intention to purchase was measured using a three item scale (Dodds, Monroe and Grewal, 1991). These three items were also evaluated on a seven point Likert-like scale where $1=$ very low and 7 = very high. 


\section{Analysis And Results}

Cronbach alpha reliabilities were performed on the brand equity scale and on the intent to purchase scale. The overall reliability alpha of the multimeasure brand equity scale by Yoo and Donthu (1997) was .975. The overall Cronbach reliability alpha for the intent to purchase scale was .945. In order to test the hypotheses, a single composite measure of perceived brand equity was calculated by averaging the ten measures of brand equity. The next step in the analysis involved comparing the brand equity and likelihood of purchase for the original or constituent brands with those of the resulting co-brands. Analysis of variance (ANOVA) along with pairwise comparisons using Scheff $\vartheta$ tests were performed to see if significant differences in brand equity and likelihood to purchase existed between the original brands and the new co-brands.

As can be seen in Table 1, significantly higher mean evaluations of brand equity were recorded for the high equity brand, Campbell, $\left(\mathrm{T}_{5}\right)$, than for the low equity brand, Equality $\left(\mathrm{T}_{2}\right)$. The perceived brand equity of the new cobrand $\left(\mathrm{T}_{4}\right)$ resulting from the pairing of the U. S. high equity brand, Campbell $\left(\mathrm{T}_{5}\right)$, with the Canadian low equity brand, Equality $\left(\mathrm{T}_{2}\right)$ was significantly higher than the perceived brand equity of Equality $\left(\mathrm{T}_{2}\right)$ at the $\mathrm{p}<.05$ level, confirming Hypothesis 1 . Hypothesis 2 was also supported in that the perceive brand equity of the composite brand or new co-brand $\left(\mathrm{T}_{4}\right)$ was significantly lower at the $\mathrm{p}<.05$ level than the high equity brand, (Campbell, $\mathrm{T}_{5}$ ), by itself. The same relationship was found for likelihood to purchase. Thus, co-branding a low equity brand with a high equity brand did help the low equity brand (see Figure 1), but it also produced a co-brand with the potential to hurt the stronger brand.

When one views Table 1B, significant differences between the three treatments $\left(T_{1}, T_{3}\right.$ and $\left.T_{5}\right)$ were noted at the $\mathrm{p}<.05$ level were noted. When the two high equity brands, Maruchan $\left(\mathrm{T}_{1}\right)$ and Campbell $\left(\mathrm{T}_{5}\right)$, were combined to form the new co-brand $\left(\mathrm{T}_{3}\right)$, the respondents' mean evaluations of brand equity of the new co-brand were significantly higher at the $\mathrm{p}<.05$ level than for the individual high equity brands, lending support to the third hypothesis. This was also true for the likelihood to purchase. These synergistic effects enhancing the brand equity perceptions of even two high equity brands are portrayed graphically in Figure 2.

\section{Discussion and Conclusion}

This study makes an initial attempt to investigate the impact of co-branding internationally. The results of this study should be considered exploratory and caution should be exercised when interpreting the results. However, in spite of any limitations, the study does indeed have some strengths and the results might provide useful to marketers. Certainly one of its strengths is the sample used in this study. The brand equity perceptions from 1,203 Philippine housewives were gathered using a stratified random sample to ensure that all four metropolitan areas were equally represented and that the sample was representative of the Philippine population as a whole in terms of various demographic characteristics. Thus, this sample eliminated two concerns of Samiee (1994). They were: too much research is limited in its generalizability due to the use of student samples and too much international research focuses on industrialized, Westernized countries. This study looked at brand perceptions in a very different market context, since the Philippines is an Asian market which is not highly industrialized. Additionally, it used actual Philippine consumers as subjects rather than gathering data from a student sample.

The principal findings demonstrate that high equity brands tend to act as augmenting cues in the perception of brand equity of a new composite or co-brand between high and low equity brands. Thus, there can be no doubt that cobranding with a high equity brand is a win-win situation for a low equity brand. The Canadian brand of ramen noodles was little known in the Philippine market, so co-branding with Campbell's would give it easier access to the market and allow it to command a more premium price (Hulland, Todino and Lecraw, 1996). This certainly would help Canadian products enter the Asian market in greater numbers, which is an area targeted by the Canadian government for export expansion in an effort to reach their goal of reversing the ratio of raw materials to consumer products exported from 60:40 to 40:60 in the next decade (Statistics Canada, 2000).

Nonetheless, one must ponder what the motivation might be for the high equity brand to consider co-branding with a lower equity brand. One can clearly see in Table $1 \mathrm{~A}$ that the mean of the perceived brand equity of the co-brand 
Table 1

Multiple Comparisons

Brand Equity: Co-Brands and Constituent Brands

\section{A Low-High Brand Equity Co-branding}

T2

Low Equity
Equality
$\mathrm{N}=286$

3.25

(.44)

3.04

(.78)

5.62

(.90)

T4

$\begin{array}{cc}\begin{array}{c}\text { Co-Brand } \\ \text { Equ/Camp } \\ \mathrm{N}=212\end{array} & \begin{array}{c}\text { F value } \\ \text { (Sig.) }\end{array} \\ 5.09 & 4599.0 \\ (.19) & (.000) \\ & \\ 5.08 & 863.4 \\ (.42) & (.000)\end{array}$

\section{B High-High Brand Equity Co-branding}

T1

$$
\begin{gathered}
\text { High Equity } \\
\text { Maruchan } \\
\mathrm{N}=294
\end{gathered}
$$

\subsection{7}

$(.25)$

6.15

$(.52)$
T5

High Equity
Campbell
$\mathrm{N}=199$

T3

$\begin{array}{cc}\begin{array}{c}\text { Co-Brand } \\ \text { Mar/Camp } \\ \mathrm{N}=212\end{array} & \begin{array}{c}\text { F value } \\ \text { (Sig.) }\end{array} \\ & \\ 6.55 & 226.9 \\ (.16) & (.000) \\ & \\ 6.36 & 73.7 \\ (.48) & (.000)\end{array}$

Scheffe's

Multiple

Comparisons

$*$

$*$

* All brands are significantly different from each other at $p<.05$.

between the low equity brand of ramen noodles and Campbell's flavoring mix, 5.09, is significantly lower than the brand equity of the constituent brand, Campbell's at 6.08. Likewise, the intent to purchase the new co-brand (5.08) is significantly less than the intent to purchase the stronger original brand, Campbells (5.62). The actual intent to purchase is, of course, of prime concern to marketers. Thus, as Simonin and Ruth (1998) point out, brands need to be careful of "the company keep" so that any brand alliances do not negatively impact the consumer brand attitudes toward the constituent or original brand, here, Campbell's. As previously described, there are certainly "spillover effects" from such co-branding activity and consumer attitudes toward the brand alliance, as well as toward the original lower equity brand, have been shown to influence subsequent impressions of each partner's brand. Additionally, each partner brand is not necessarily affected equally by its participation in a particular co-brand.

What possible motivation then would a high brand equity brand have to co-brand with a brand perceived as having lower brand equity? In the international arena the answer might lie in a situation where brand $\mathrm{A}$ is perceived as having high brand equity in Market $\mathrm{X}$, but not in market $\mathrm{Y}$, and the reverse is true for brand $\mathrm{B}$. Thus, assuming they are products which would be a compatible co-brand, the alliance could benefit both. This assumes that neither brand has a negative image in either market, but simply lacks brand awareness or recognition. An example of such an alliance would be that of Wendy's and Tim Horton's. Wendy's had a very strong image and presence in the U.S. market, but had achieved little success or penetration in the Canadian market. The reverse situation was true of Tim Horton's. The alliance of these two brands has been greatly beneficial to both companies in their efforts to penetrate a new market. If a 
Figure 1

Co-branding of Equality and Campbell

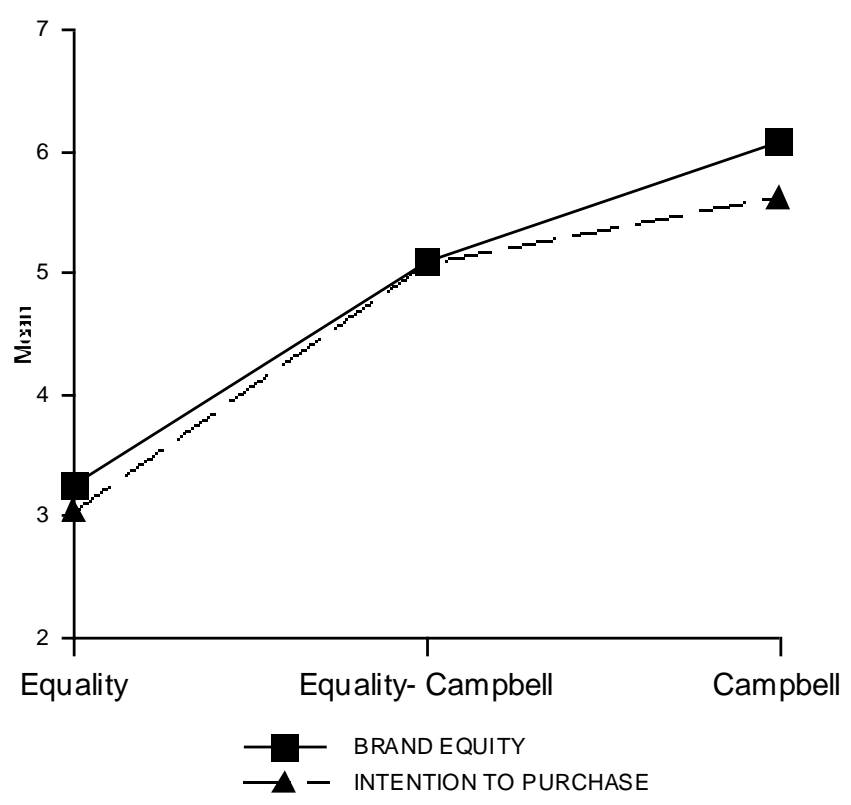

Figure 2

Co-branding of Maruchan and Campbell

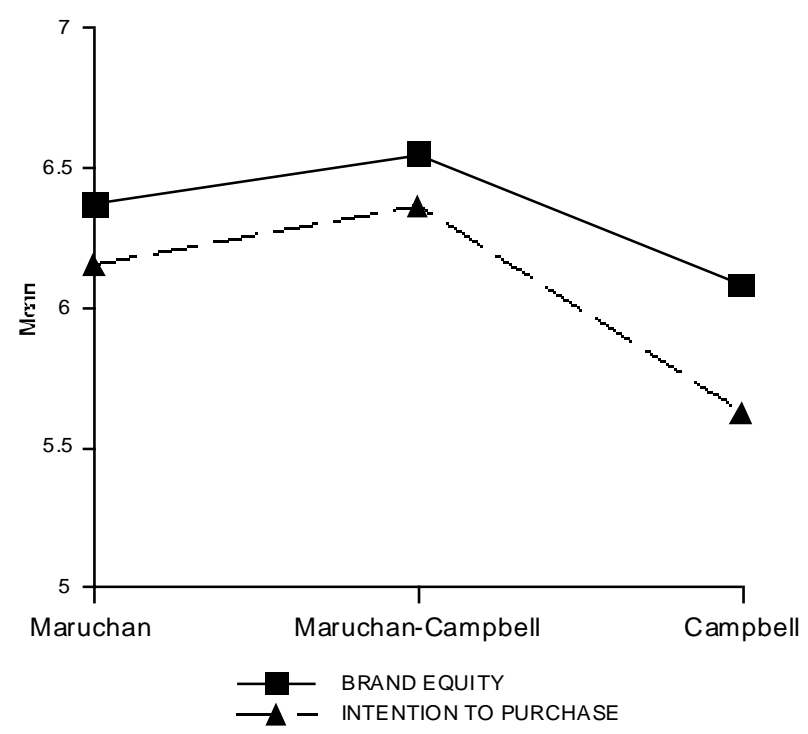

high equity brand would co-brand with one which had a negative image in a particular market, the resulting co-brand might not only be viewed as negative, but also the spillover effects of that alliance could hurt the brand equity of the constituent brand in that market, as well as its global image in the international arena. 
Lastly, if one looks at the situation of a high brand equity brand partnering with another strong brand, such as treatment 3 (see Table 1B) in this study, where Maruchan ramen noodles were co-branded with Campbell's flavoring mix, one sees that the perceived brand equity of the new co-brand (6.55) was actually significantly higher than either constituent's brand equity (6.37 and 6.08). Hence, even strong brands can benefit from such a branding alliance. Similarly, the intent to purchase the new co-brand (6.36) was significantly higher than the intent to purchase either of the constituent or original brands (6.15 and 5.62, respectively). However, as Morrin's (1999) research and this study demonstrate, it is the nondominant brands (those of low brand equity) which benefit most from such co-branding activities.

Thus, co-branding is a marketing alternative which can offer many benefits, if it is handled wisely. It can enhance the sales potential of a product or service, help a brand owner gain access to new countries or regions, minimize the investment needed to enter new markets and offer the possibility of quicker returns on marketing investment. The synergy of two recognized brands, harnessed together, can quickly translate into customer interest and response and may bring instant performance in the marketplace (Blackett and Boad, 1999).

However, as in any other type of alliance, there are considerable risks to a brand's reputation if the wrong partner brand is used. In selecting a partner brand, one needs to thoroughly investigate the background and reputation of the brand, as well as the values of the firm. Both partners should view the co-branding activity as contributing to longterm brand value, not as a way to "make a fast buck." Once the co-brand has been established, both partners must work together and maintain consistency, not only in how the new co-brand is portrayed, but also the constituent or partner brands, because they will become closely associated in the consumers' minds. The new co-brand's positioning must be supported not only by the product's characteristics, but also by the advertising message, price points and choice of distribution outlets (Buchanan, Simmons and Bickart, 1999). This consistency must extend to the retailer level and how the new co-brand is displayed, because inconsistencies in brand communication may lead to reevaluation of the new cobrand, as well as the partner brands.

The co-branding agreement needs to provide for the possibility of termination in the event that the partner brand or co-brand suffers a serious reputation problem. This disassociation would need to be accomplished as quickly and completely as possible to minimize damage to the original brand(s), because problems related to co-branding have been found to have negative reciprocal effects (Swaminathan, Fox and Reddy, 2001).

Hence, brand owners considering co-branding should investigate the potential partner's brand image, not only in the market being considered for the co-branding activity, but also worldwide, since in today's technological world brand images are truly global brand images (Roth, 1995). The long-term effect of the potential co-branding also needs to be carefully evaluated. Some researchers, such as Janiszewski and Osselaer (2000), have found that co-branding is most valuable in promoting trial of new products and in entering new markets, but that it can decrease or limit the value of both partner brands in the long run. Thus, as Douglas (2001) advocates, a firm needs to build an international brand architecture which establishes how brands are used and extended across product lines and the extent of brand coordination across national boundaries. If co-branding is well thought out, the brands in a co-brand act as "receptacles for the customer goodwill arising from the successful union" (Blackett and Boad, 1999, xvii). Because strong international brands often have high visibility, an ill-advised co-branding activity can cause irreparable harm in multiple markets. As Simonin and Ruth $(1998,30)$ put it, "a company may be known by the company it keeps!" A co-brand is like the marriage of two brands, so choose your partners wisely!

\section{Limitations and Suggestions for Future Research}

The recommendations in this study are set forth, of course, with the caveat as to the limitations of the sample, which was made up of housewives in four metropolitan areas of the Philippines. Nonetheless, it is believed that the results of this study will alert firms not only to the potential rewards to be gained from co-branding but also to the potential threats to the brand equities of the original constituent brands. However, to provide a more comprehensive picture of the impact of co-branding, similar studies could be done in other countries using both other product categories and other brands. Also, the brands investigated in this study were all brands originating from developed or industrialized 
countries; future research could use a brand from a developing country as one of the constituent brands for the composite or co-brand to see the impact of this on the resulting brand equity of the co-brand. In this study, the lower equity Canadian brand did not have a negative image in the Philippine market; the consumers were simply not aware of nor had knowledge of the Canadian brand. A future study might use a brand with a negative image in a particular market to investigate whether the high equity brand could actually overcome that negative image in a co-branding situation. Lastly, future research could examine moderators that might influence the success of a co-branding strategy in an international setting (i.e., competitor actions, government regulations, cultural issues, etc.).

Acknowledgments: The co-authors wish to thank Victor Cabiles and Dotie Babel from TNS Philippines for their invaluable help in data collection.

\section{References}

1. $\quad$ Aaker, David A., "Building Strong Brands", The Free Press, New York, 1996.

2. _ _ Managing Brand Equity, New York Press, New York, 1991.

3. Alba, Joseph W. and Amitava Chattopadhyay, "The Effects of Context and Part-Category Cues on Recall and Competing Brands," Journal of Marketing Research, Vol. 1, 22 (August), pp. 340-349, 1985.

4. Anderson, John R., "A Spreading Activation Theory of Memory," Journal of Verbal Learning and Verbal Behavior, Vol. 22 (3), pp. 261-295, 1983.

5. Balachander, Subramanian and Sanjoy Ghose, "Reciprocal Spillover Effects: A Strategic Benefit of Brand Extensions," Journal of Marketing, Vol. 67 (1), pp. 4-13, 2003.

6. Batra, Rejeev, VenKatram Ramaswamy, Dana L. Alden, E. M. Jan-Benedict Steenkamp and S. Ramachander, "Effects of Brand Local and Nonlocal Origin on Consumer Attitudes in Developing Countries," Journal of Consumer Psychology, Vol. 9(2), pp. 83-95, 2000.

7. Bello, David C. and Morris B. Holbrook, "Does an Absence of Brand Equity Generalize Across Product Classes," Journal of Business Research, Vol. 34, pp. 125-131, 1995.

8. Blackett, Tom and Bob Boad, Co-Branding: The Science of Alliance, St. Martin's Press, New York, 1999.

9. Buchanan, Lauranne, Carolyn J. Simmons and Barbara A. Bickart, "Brand Equity Dilution: Retailer Display and Context Brand Effects," Journal of Marketing Research, Vol. 36 (August), pp. 345-355, 1999.

10. Brouthers, Lance Elliot and Kefeng Xu, "Product Stereotypes, Strategy and Performance Satisfaction: The Case of Chinese Exporters," Journal of International Business Studies, Vol. 33 (4), pp. 657-677, 2002.

11. Chakravarti, Dipankar, Deborah J. Macinnis and Kent Nakamoto, "Product Category Perceptions, Elaborative Processing and Brand Name Extension Strategies," in Advance in Consumer Research, Thomas Srull, ed., Association for Consumer Research, Provo, Utah, Vol. 16, pp., 910-916, 1989.

12. Chaudhuri, Arjun and Morris B. Holbrook, "The Chain of Effects from Brand Trust and Brand Affect to Brand Performance: The Role of Brand Loyalty," Journal of Marketing, Vol. 65 (April), pp. 81-93, 2001.

13. Country Commercial Guide, U.S. \& Foreign Commercial Service and U.S. Department of State, 2002.

14. Dawar, Niraj and Madan M. Pillutla, "Impact of Product-Harm Crises on Brand Equity: The Moderating Role of Consumer Expectations," Journal of Marketing Research, Vol. 37 (2), pp. 215-226, 2000.

15. de Chernatony, Leslie, "Developing on Effective Brand Strategy". In C. Egan and M. Thomas (ed), The Chartered Institute of Marketing Handbook of Strategic Marketing, Butterworth Heinemann, Oxford, 1998.

16. Dillon, William R., Thomas J. Madden, Amna Kirmani and Soumen Mukherjee, "Understanding What's in a Brand Rating: A Model for Assessing Brand and Attribute Effects and Their Relationship to Brand Equity," Journal of Marketing Research, Vol. 38 (4), pp. 415-429, 2001.

17. Dodds, William B., Kent B. Monroe and Dhruv Grewal, "The Effects of Price, Brand and Store Information on Buyers' Product Evaluations,” Journal of Marketing Research, Vol. 28 (August), pp. 307-319, 1991.

18. Douglas, Susan P., "Executive Insights: Integrating Brand Strategy Across Markets: Building International Brand Architecture," Journal of International Marketing, Vol. 9 (2), pp. 97-114, 2001.

19. Erdem, Tulin and Baohong Sun, "An Empirical Investigation of the Spillover Effects of Advertising and Sales Promotion in Umbrella Branding," Journal of Marketing Research, Vol. 39 (4), pp. 408-420, 2002.

20. and Joffre Swait, "Brand Equity as a Signaling Phenomenon," Journal of Consumer

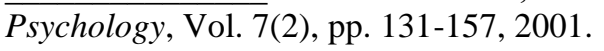


21. Green, Robert T. and Tasman Smith, "Executive Insights: Countering Brand Counterfeiters," Journal of International Marketing, Vol. 10 (4), pp. 89-106, 2002.

22. Heilman, Carrie M., Douglas Bowman and Gordon P. Wright, "The Evolution of Brand Preferences and Choice Behaviors of Consumers New to a Market", Journal of Marketing Research, Vol. 38 (May), pp. 139-155, 2000.

23. Hillyer, Clayton and Surinder Tikoo, "Effects of Co-Branding on Consumer Product Evaluations, Advances in Consumer Research, Vol. 22, pp. 123-127, 1995.

24. Hsieh, Ming H., "Identifying Brand Image Dimensionality and Measuring the Degree of Brand Globalization: A Cross-National Study," Journal of International Marketing, Vol. 10 (2), pp. 46-67, 2002.

25. Hulland, John, Honorio S. Todino and Donald L. Lecraw, "Country of Origin Effects on Sellers' Price Premiums in Competitive Philippine Markets," Journal of International Marketing, Vol. 4(1), pp. 57-79, 1996.

26. Janiszewski, Chris and Stijn M. J. Van Osselaer, "A Connectionist Model of Brand-Quality Associations," Journal of Marketing Research, Vol. 37 (August), pp. 331-350, 2000.

27. Jevons, Colin and Mark Gabbott, "Trust, Brand Equity and Brand Reality in Internet Business Relationships: An Interdisciplinary Approach," Journal of Marketing Management, Vol. 16, pp. 619-634, 2000.

28. Keller, K. L., "Brand Knowledge Structures," in Strategic Brand Management: Building, Measuring and Managing Brand Equity, Prentice Hall, Upper Saddle River, NJ, pp. 86-129, 1998.

29. _C "Conceptualizing, Measuring, and Managing Customer-Based Brand Equity," Journal of Marketing, Vol. 57, pp. 1-22, 1993.

30. Kirmani, Amna, Sanjay Sood and Shen Bridges, "The Ownership Effect in Consumer Responses to Brand Line Stretches," Journal of Marketing, Vol. 63 (January), pp. 88-101, 1999.

31. Klink, Richard R. and Daniel C. Smith, "Threats to the External Validity of Brand Extension Research," Journal of Marketing Research, Vol. 38 (August), pp. 326-335, 2001.

32. Malhotra, Naresh K., Mark Peterson and Susan Bardi Kleiser, "Market Research: A State-of-the-Art Review and Directions for the Twenty-First Century," Journal of the Academy of Marketing Science, Vol. 27 (2), pp. 160-183, 1999.

33. Martin, Ingrid M. and David W. Stewart, "The Differential Impact of Goal Congruency on Attitudes, Intentions and the Transfer of Brand Equity," Journal of Marketing Research, Vol. 38 (4), pp. 471-484, 2001.

34. Moore, Elizabeth S., William Wilkie and Richard J. Lutz, "Passing the Torch: Intergenerational Influences as a Source of Brand Equity," Journal of Marketing, Vol. 66 (2), pp. 17-37, 2002.

35. Morrin, Maureen, "The Impact of Brand Extensions on Parent Brand Memory Structures and Retrieval Processes," Journal of Marketing Research, Vol. 37 (November), pp. 517-525, 1999.

36. Park, C. Whan, Sung Youl Jun and Allan D. Shocker, "Composite Branding Alliances: An Investigation of Extension and Feedback Effects," Journal of Marketing Research, Vol. 33(4), pp. 453-466, 1996.

37. Pernia, Elena, "Advertising in the Philippines: Communication, Culture and Consumption," in Katherine Toland Frith (ed), Advertising in Asia: Communication, Culture and Consumption, Iowa State University Press, Ames, Iowa, 1996.

38. Rao, Akshay R. and Robert W. Ruekert, "Brand Alliances as Signals of Product Quality," Sloan Management Review, Vol. 36 (Fall), pp. 87-97, 1994.

39. Ratneshwar, Srinivasan and Allan D. Shocker, "Substitution in Use and Role of Usage Context in Product Category Structures," Journal of Marketing Research, Vol. 28 (August), pp. 281-295, 1991.

40. "Rise in Philippines' Portfolio Inflow," Asia Weekly Financial Alert, Vol. 5 (45), pp. 7-12, 2002.

41. Roth, Martin S., "The Effects of Culture and Socioeconomics on the Performance of Global Brand Image Strategies," Journal of Marketing Research, Vol. 32 (May), pp. 163-175, 1995.

42. Samiee, Saeed, "Consumer Evaluation of Products in a Global Market," Journal of International Business Studies, Vol. 25 (3), pp. 579-604, 1994.

43. Simonin, Bernard L. and Julie A. Ruth, "Is a Company Known by the Company it Keeps? Assessing the Spillover Effects of Brand Alliances on Consumer Brand Attitudes," Journal of Marketing Research, Vol. 35 (February), pp. 30-42, 1998.

44. Srivastava, Rajendra K. and Allan D. Shocker, "Brand Equity: A Perspective on its Meaning and Measurement," Marketing Science Institute Working Paper No. 910 124, Marketing Science Institute, Cambridge, MA, 1991.

45. Statistics Canada, Government of Canada, Ottawa, Ontario, 2000. 
46. Stigler, G. D., “The Economics of Information,” Journal of Political Economy, Vol. 69, pp. 13-26, 1961.

47. Swaminathan, Vanitha, Richard J. Fox and Srinivas K. Reddy, "The Impact of Brand Extension Introduction on Choice," Journal of Marketing, Vol. 65 (October), pp. 1-15, 2001.

48. Temporal, Paul, Branding in Asia: The Creation, Development and Management of Asian Brands for the Global Market, Wiley, New York, 2000.

49. Vasquez, Rodolfo, A. Belen Del Rio, and Victor Iglesias, "Consumer-Based Brand Equity: Development and Validation of a Measurement Instrument," Journal of Marketing Management, Vol. 18 (1/2), pp. 27-48, 2002.

50. Washburn, Judith H. and Richard E. Plank, "Measuring Brand Equity: An Evaluation of a Consumer-Based Brand Equity Scale," Journal of Marketing Theory and Practice, Vol. 10 (1), pp. 46-61, 2002.

51. _ _ Brian, D. Till and Randi Priluck, "Co-Branding: Brand Equity and Trial Effects," Journal of Consumer Marketing, Vol. 17 (Winter), pp. 44-53, 2000.

52. Wellman, David, “Let’s Go Team (Up)," Supermarket Business, Vol. 55 (1), pp. 50-51, 2000.

53. Wells, H. G., The Open Conspiracy, ed. Warren Wagar, Connecticut: Praeger, 2002.

54. Wiedemann, George S., "To Reinforce a Branding Message, Total Communications Coordination is a Must," presentation to the Direct Marketing Association, October, New York City, 1999.

55. Yoo, Boonghee and Naveen Donthu, "Developing and Validating a Consumer-Based Overall Brand Equity Scale for Americans and Koreans: An Extension of Aaker's and Keller's Conceptualizations," presented at American Marketing Association's Summer Educators' Conference, Chicago, Illinois, 1997.

56. Zhang, Shi and Bernd H. Schmitt, "Creating Local Brands in Multilingual International Markets," Journal de Marketing Research, Vol. 38 (August), pp. 313-325, 2001.

\section{Appendix 1 \\ Brand Equity Questions}

The quality of brand $\mathrm{X}$ is extremely high.

The likelihood that brand $\mathrm{X}$ would be functional is extremely high.

I consider myself to be loyal to brand $X$.

Brand $\mathrm{X}$ would be my first choice.

I will not buy other brands if brand $\mathrm{X}$ is available at the store.

I can recognize brand $X$ among other competing brands.

I am aware of brand $X$.

I can quickly recall the symbol or logo of brand X.

It makes sense to buy brand $\mathrm{X}$ instead of any other brand, even if they are the same.

Even if another brand has the same features as brand X, I would prefer to buy brand X. 